\title{
EGY ÚJRA MŰKÖDŐ SZÉLMALOM TÖRTÉNETE
}

\section{THE STORY OF A RE-OPERATING WINDMILL}

\author{
Bitay Enikő, ${ }^{1}$ Márton László, ${ }^{2}$ Talpas János ${ }^{3}$ \\ ${ }^{1}$ Sapientia Erdélyi Magyar Tudományegyetem, Marosvásárhelyi Kar, Marosvásárhely, Románia, \\ ebitay@ms.sapientia.ro \\ ${ }^{2}$ Erdélyi Múzeum-Egyesület, Gyergyószentmiklós, martonlb@yahoo.com \\ ${ }^{3}$ Babeş-Bolyai Tudományegyetem, Földrajz Kar, Kolozsvár, talpasjanos@gmail.com
}

\begin{abstract}
Research on the history of the development of grain milling structures is a priority topic of the Department of Technical Sciences of the Transylvanian Museum Association. Quite a few publications and study volumes contain the results of the research. The present dissertation presents another grinding structure, the windmill, its reconstruction, creating a connection between the theoretical foundations and the practical implementation. Although it was built as a museum and tourist object, it is also a significant work from the point of view of technical history.

The Felsőszentiván windmill is powered by a 14-meter-diameter windmill. The mill has a two-stage accelerator gear that increases the low, non-grinding speed of the wind turbine for the rotation typical of grindstone mills.

The upper stones of a pair of grindstones rest on a vertical axis, and by raising this the gap between the stones can be adjusted. This determines the particle size of the grind. The windmill consists of three functional parts: a windmill, an accelerator gear and a grain mill made up of a pair of grindstones.
\end{abstract}

Keywords: windmill, gear transmission, grinding, grindstone pair.

\section{Összefoglalás}

A gabonaőrlő szerkezetek fejlődéstörténetének kutatása az Erdélyi Múzeum-Egyesület Műszaki Tudományok Szakosztályának kiemelt témaköre. Jó néhány közlemény, tanulmánykötet tartalmazza a kutatások eredményeit. Jelen dolgozat egy újabb őrlőszerkezetet, a szélmalmot, annak újraépítését mutatja be, kapcsolatot teremtve az elméleti alapok és a gyakorlati kivitelezés között. Bár muzeális és turisztikai objektumként épült, technikatörténeti szempontból is jelentős alkotás.

A felsőszentiváni szélmalmot egy 14 méter átmérőjű szélkerék hozza működésbe. A malomnak kétlépcsős gyorsító fogaskerék áttétele van, ami az őrlőköves gabonamalmokra jellemző forgásra növeli a szélkerék alacsony, az őrlésre alkalmatlan fordulatát.

Az őrlőkő pár felső köve egy függőleges tengelyre támaszkodik, ennek emelésével lehet szabályozni a kövek közötti rést. Ez határozza meg az őrlemény szemcseméretét. A szélmalom három funkcionális részből tevődik össze: a szélkerékből, a gyorsító fogaskerék-áttételekből és az őrlőkőpárból kiépített gabonamalomból.

Kulcsszavak: szélkerék, fogaskerék-áttételek, őrlés, ôrlőkőpár.

\section{Bevezető}

A szélkerék a szélmalmok jellegzetes szerkezeti eleme, a szél mozgási energiáját alakítja át forgómozgássá. Az első szélmalmok a 7. században épültek, Irán és Afganisztán termékei függőleges tengelyűek voltak. A harmadik keresztes hadjárat (1189-1192) résztvevői vitték a Közel-Keletre Nyugat-Európa termékét, a vízszintes tengelyü szélmalmot. A Kárpát-medencében a 12. század- 
tól ismert a szélmalom, ilyenek ott épültek, ahol gyors folyású patakok hiányában vízimalmok nem hódíthattak teret [1]. A szélmalmok helyének kiválasztásánál figyelembe kellett venni a szélsebesség éves átlag értékét, aminek 2-5 m/s között kellett lennie. A szél sebességének változása a domborzat és a talajszint fölötti magasság függvényében az 1. ábrán követhető.

Az évszázadok folyamán a szélmalmok egyre bonyolultabbak, tökéletesebbek, és a 19. századra már a mai változatát alkalmazták. Így vált a szélmalom fontos és olcsó mechanikai energiaforrássá. Szintén a 19. századhoz kapcsolódik a gőzgép diadalútja és a szélmalom vetélytársává válása.

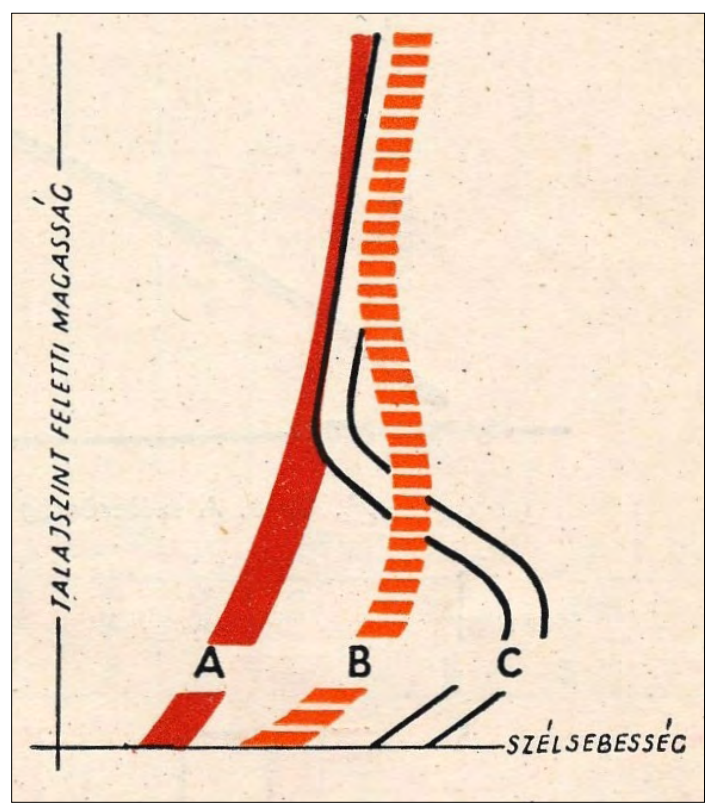

1. ábra. A szél sebességének változása a domborzat és a talajszint fölötti magasság függvényében. [2]. $A$ - sík vidéken, $B$ - enyhén dombos vidéken, $C$ - hegyvidéken

\section{A szélmalom rendeltetése, alkalma- zási területe}

A szélmalom elsősorban gabonafélék-, valamint szemeskukorica-őrlemény előállítására szolgál. Az őrlemény a szita nélküli, őrlőköves malmok termékeire jellemző teljes kiőrlésű dara. A termék rendeltetésszerüen állati takarmányként használható, a kukoricadara kézi kiszitálás után emberi eledelként is használhatóvá válik.
Őrlési kapacitása a kis malmok kategóriájába sorolja. Alkalmazásával energiatakarékos módon jó minőségű állati takarmány az őrlemény kiszitálása után emberi táplálék alapanyagául is felhasználható. A szélmalom teljes kiőrlésű búza vagy rozsliszt előállítására is alkalmas a primer őrlemény megfelelő sűrűségű szitán való átszitálása után.

Üzemmód tekintetében a malommal mind folyamatos, mind szakaszos technológia megvalósítható. Felhasználható folyamatos őrlemény előállítására vagy a lakossági igények ellátására egyaránt.

\section{A szélmalom működése}

A szélmalom müködését három gépszerkezet határozza meg:

- gabonatisztító szerkezet;

-őrlőszerkezet;

- az energiaátvivő szerkezet.

\subsection{A gabonatisztító szerkezet}

Az első szinten (földszint) kezdődik a technológiai folyamat, a gabona tisztításának második fázisa a koptatás. A tisztítás első fázisát a gabonaraktárban található rosta és szelektor (triör) végzi, már a gabona malomba szállítása előtt. Ebben a tisztítási fázisban a gabonától minden idegen anyagot eltávolítanak. Az őrlésre csak a megtisztított gabona kerül. Amint említettük, a tisztítás második fázisa a koptatás. A földszinten található koptató vagy hántoló a gabonaszemeket forgásuk közben megtisztítja azáltal, hogy a szemek a koptató belső, hengeres burkolatát képező, szögletes keresztmetszetű acél huzalból készült szitaszövethez hasonló felülethez ütköznek. Az ütközés következtében a szemek felületéről a szögletes huzal élei eltávolítják a felületi réteget, ami a nemkívánatos szennyező anyagokat tartalmazza. A leválasztott héjréteget a koptatóhoz tartozó elszívó ventilátor eltávolítja, és egy ülepítő ciklonba és porszűrő zsákba továbbítja. A felületi szennyező anyagoktól megtisztított gabonát a koptató forgó labodái tengely irányú mozgásra kényszerítik. A koptatóban a csavaros mozgás a megkoptatott szemeket a kiömlő nyílás felé tereli. A kiömlő nyílás közvetlen kapcsolatban van a gumilapátos felvonóval, ami a tiszta gabonát az első emeletre (második szint), ahol a kőpad található, emeli. Amíg a koptató működésben van, a gumilapátos felvonó is működik. 


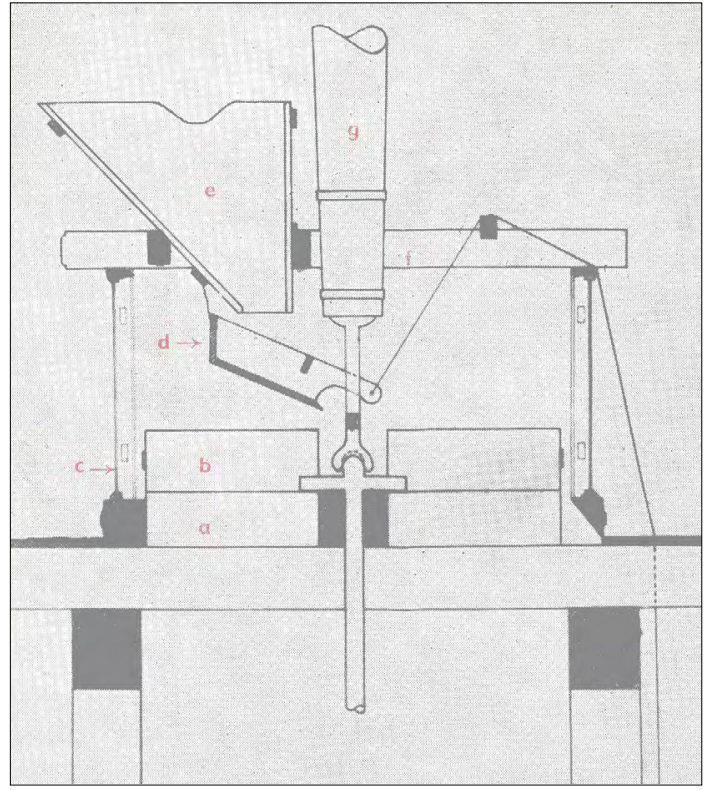

2. ábra. Az örlöszerkezet metszete [2]

\subsection{Az őrlőszerkezet}

Az őrlés folyamata az első emeleti szinten megy végbe. A gabona a koptatást követően az őrlőegység fogadó garatjába jut. Ekkor már az őrlő kőpár felső, forgó köve a villás tengely forgásának hatására forgásban van.

A nagygaratba hordott gabona a kisgaratba folyik. A kisgarat dőlésszögét szabályozásával változtathatja a molnár aszerint, hogy gyorsabban vagy lassabban akarja, hogy folyjon a gabona a kőpár közé. A kisgarat, hogy a gabona benne fel ne akadjon, állandóan rázkódik. A rázkódást a forgó kőhöz érintkező rudacska hozza létre [3, 4]. Az őrlőszerkezet metszete a 2. ábrán látható, segítségével müködése is tanulmányozható.

\subsection{Az energiaátvivő szerkezet}

Ismeretes, hogy a szél ereje sebességének négyzetével arányosan növekszik. A szél erejét sebességével vagy az $1 \mathrm{~m}^{2}$-re kifejtett nyomásával határozzák meg. A szélerő a szárazföldön napi periódus szerint változik. Délelőtt erősödő, délben a legerősebb, délután, napnyugta felé gyengül erőssége. A szél sebessége az év folyamán is változik.

$\mathrm{Az}(F)$ nagyságú vitorlafelületen másodpercenként $v \cdot F$ térfogatú levegő haladhat át. Az $F$ felületű keresztmetszetre kifejtett erő $(P)$ a sebesség köbével arányos:

$P=F \cdot v^{3} / 16$.

A szélenergia teljes kihasználása nem lehetséges, mert a szél a vitorlák között tovább mozog, nem áll le teljesen. Energiájának bizonyos hányadát lehet hasznosítani [2].

A szélkeréknél alkalmazott hatásfok értéke 0,4. Így a $\mathrm{P}$ hatóerő értéke a következő lesz:

$P=0,4 \cdot F \cdot v^{3} / 16[\mathrm{kgF}]$.

Egy vitorla ütőfelülete $7 \times 1,2=8,4 \mathrm{~m}^{2}$, így a 4,0 m/s erősségű szélben a forgatónyomaték:

$$
M=P \times L[\mathrm{kgF} \cdot \mathrm{m}],
$$

aminek teljesítménye M/75 [LE]-nek felel meg.

A szélmalom őrlési teljesítménye a szélsebesség függvénye.

Ốrlés közben a kövek kopnak, időközönként ezek őrlő felületét újra kell vágni (élezni). A müvelet szakértelmet feltételez.

\section{A felsőszentiváni szélmalom}

A felsőszentiváni szélmalom, feltételezés alapján, a 19. század közepén épülhetett, és közel száz év múlva, 1920-ban Nagy Torma Vince tulajdonába került. A malomház kúpos alakzatú fala két rétegből épült. Belső fele vályog, külső fele téglafalazású volt. Nagy Torma Vince tulajdonában 1950-ig működött, de a tulajdonosnak nem volt anyagi lehetősége, hogy a lassan, de biztosan romló malmot felújítsa [5]. Ennek hiányában 2005-ben a szélmalom falazatából több méter átmérőjű darab kiomlott (3. ábra). A maradék épületroncs használhatatlanná, mi több, veszélyessé vált. A romlásnak indult malom gépezetét a 4. ábra szemlélteti.

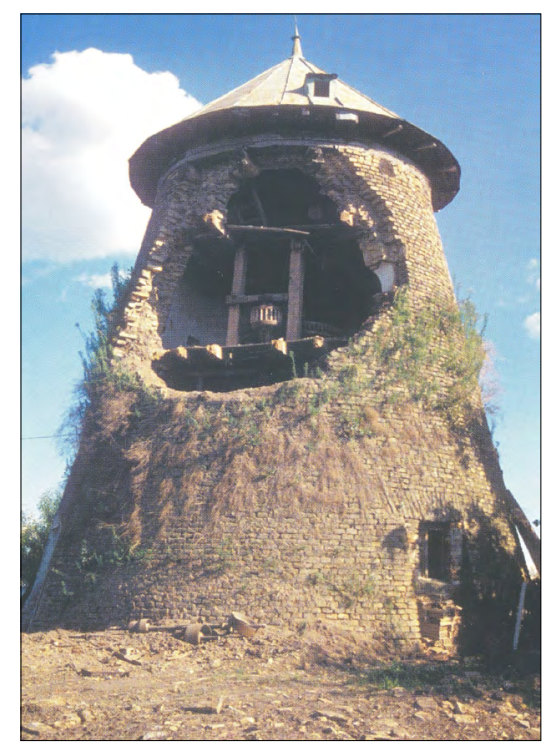

3. ábra. A felsöszentiváni szélmalom látképe újjáépitése előtt 


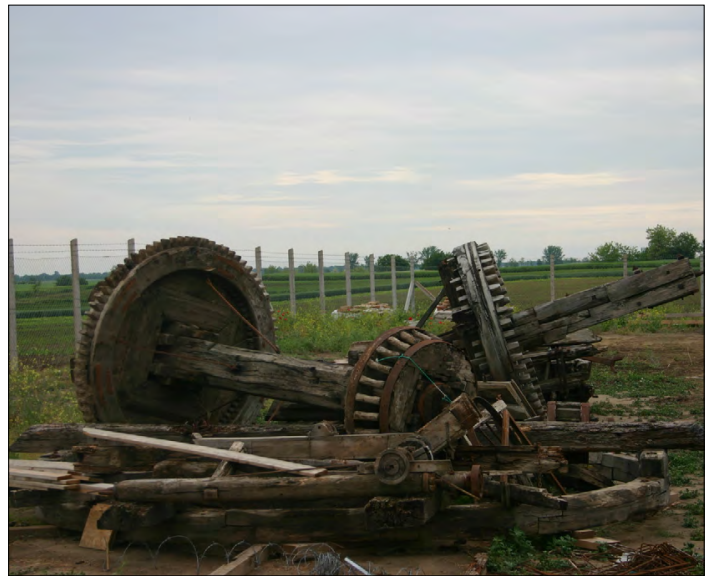

4. ábra. A romlásnak indult régi malomgépezet

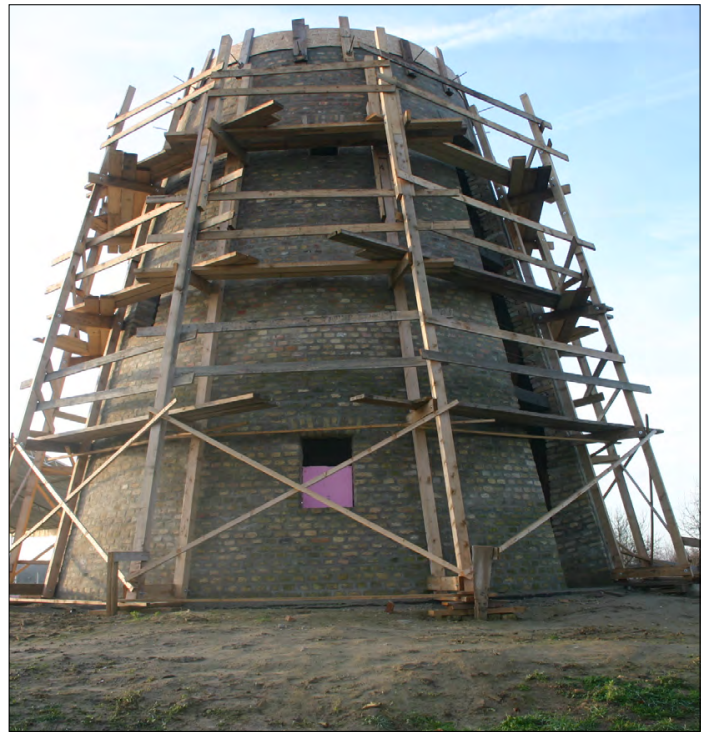

5. ábra. A felsőszentiváni szélmalom látképe újjáépítése alatt

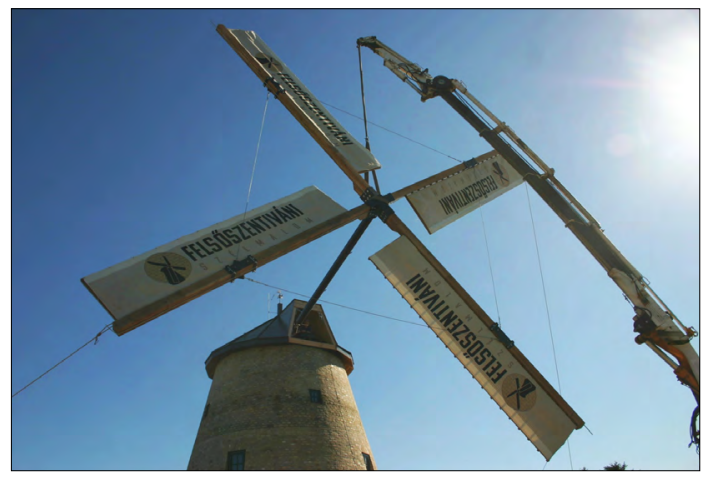

6. ábra. A szélkerék felemelése, helyretétele
A tulajdonos, Nagy Torma Vince, 1983-ban eltávozott az élők sorából. A malom további sorsának alakítását a helyi önkormányzat vette át, megvásárolta a romos malmot és a körülötte lévő telket. Európai uniós pályázati finanszírozásból újjáépíttette a szélmalmot. Az építkezési munkálatokat a Bajai Beton Kft. végezte, a malomgépezet és szélkerék elkészítésére a gyergyószentmiklósi Mecatex Kft. vállalkozott, amelynek a hagyományos őrlőszerkezetek építésében széles körű tapasztalata van. E tapasztalat megszerzésében az EME által évenként szervezett technikatörténeti táborok is dokumentálódási lehetőséget jelentettek. Mindez 2019-2020-ban történt. Mindkét kivitelező határidőre befejezte munkálatait, megépítették Magyarország egyetlen müködőképes szélmalmát (5. ábra).

Müszaki adatok:

-őrlési kapacitás: 200-250kg/óra, a szélsebesség függvényében;

-termékminőség: teljes kiőrlésű dara;

-kiőrlési százalék: 100\%, szitálás után 70-80\% a gabona minőségének függvényében;

- beszerelt teljesítmény: a két kőpár felépítésű őrlőegység, a kanalas felvonó, a koptató és a porelszívó összteljesítménye: 9 kW; - üzemeltetéséhez két személy szükséges.

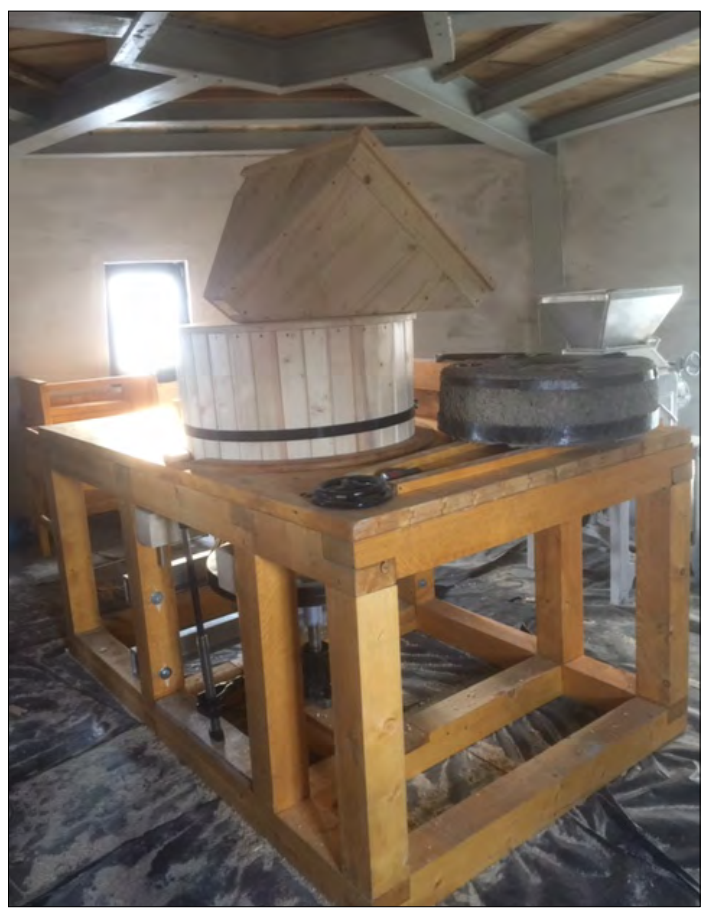

7. ábra. A szélmalom szerelés közben 


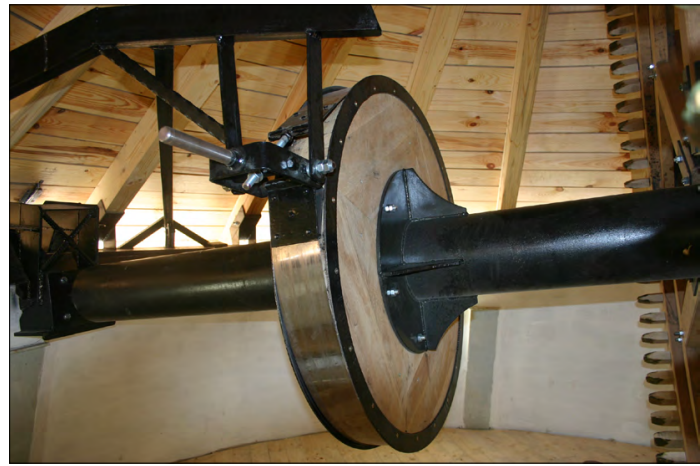

8. ábra. A szélmalom fékszerkezete

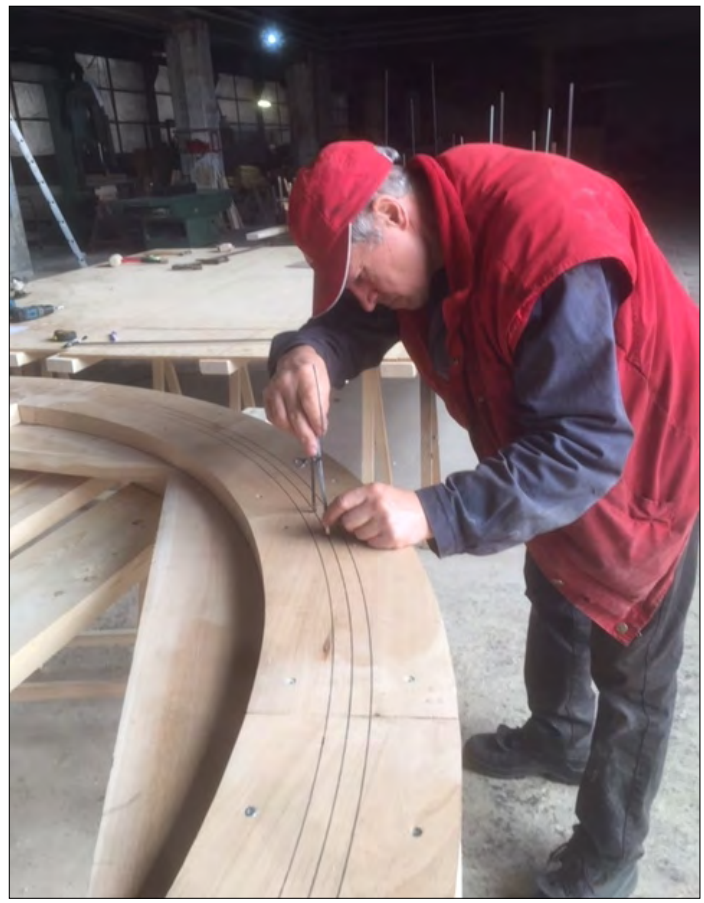

9. ábra. A fogaskerékfog beosztása

A régi és az új szélmalom is két kőpárral működő őrlőegységet tartalmaz, ezek egyszerre vagy külön-külön is működtethetők. A szélmalomgépezet és az új szélkerék felszerelését, elkészítésének mozzanatait a 6-11. ábrák szemléltetik.

\section{A szélmalom leírása, szerkezeti fel- építése}

A szakirodalom szerint a csonka kúp alakú malomépület négy szintre tagozódik [6]. A földszinti rész (I.) a lisztes pad, az első emeleti rész (II.) a kőpad, a második emeleti rész (III.) a sebeskerék-

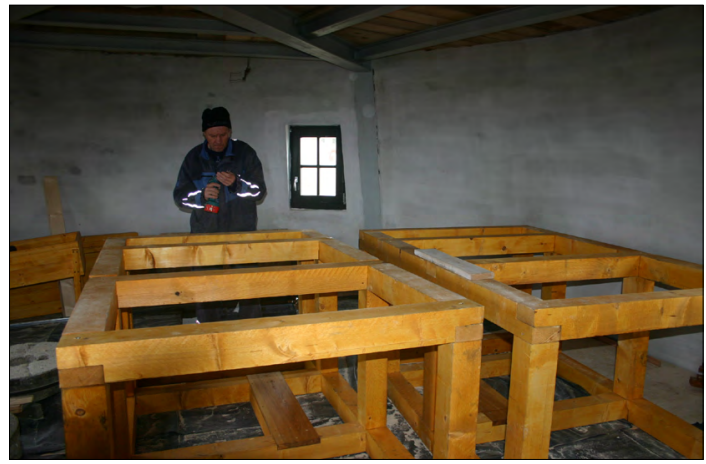

10. ábra. A malomgépezet tartószerkezetének összeszerelése

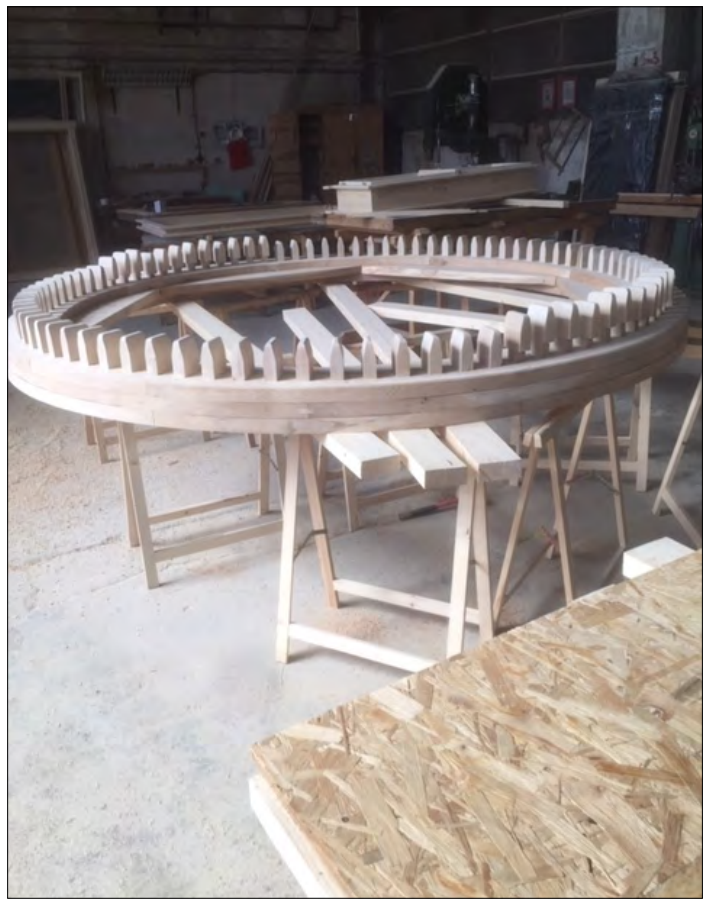

11. ábra. A félkész fogaskerék

pad, a harmadik emelet (IV.) a nagykerék padja (12. ábra). A malom téglafalának felső peremén vasbeton koszorúba kapcsolódó görgős pálya található, amely a malom tetőszerkezetének elfordítását teszi lehetővé, a szelestengellyel és az oldalfogazatú szeleskerékkel együtt.

Az oldalfogazatú szeleskerékhez kapcsolódik a nagydobkerék, az első gyorsító fokozat, ami a szeleskerék forgómozgását a függőleges síkban található bálványtengelyhez közvetíti. A bálványtengelyre a harmadik szinten található sebeskerék van rögzítve. A sebeskerék forgómozgását 


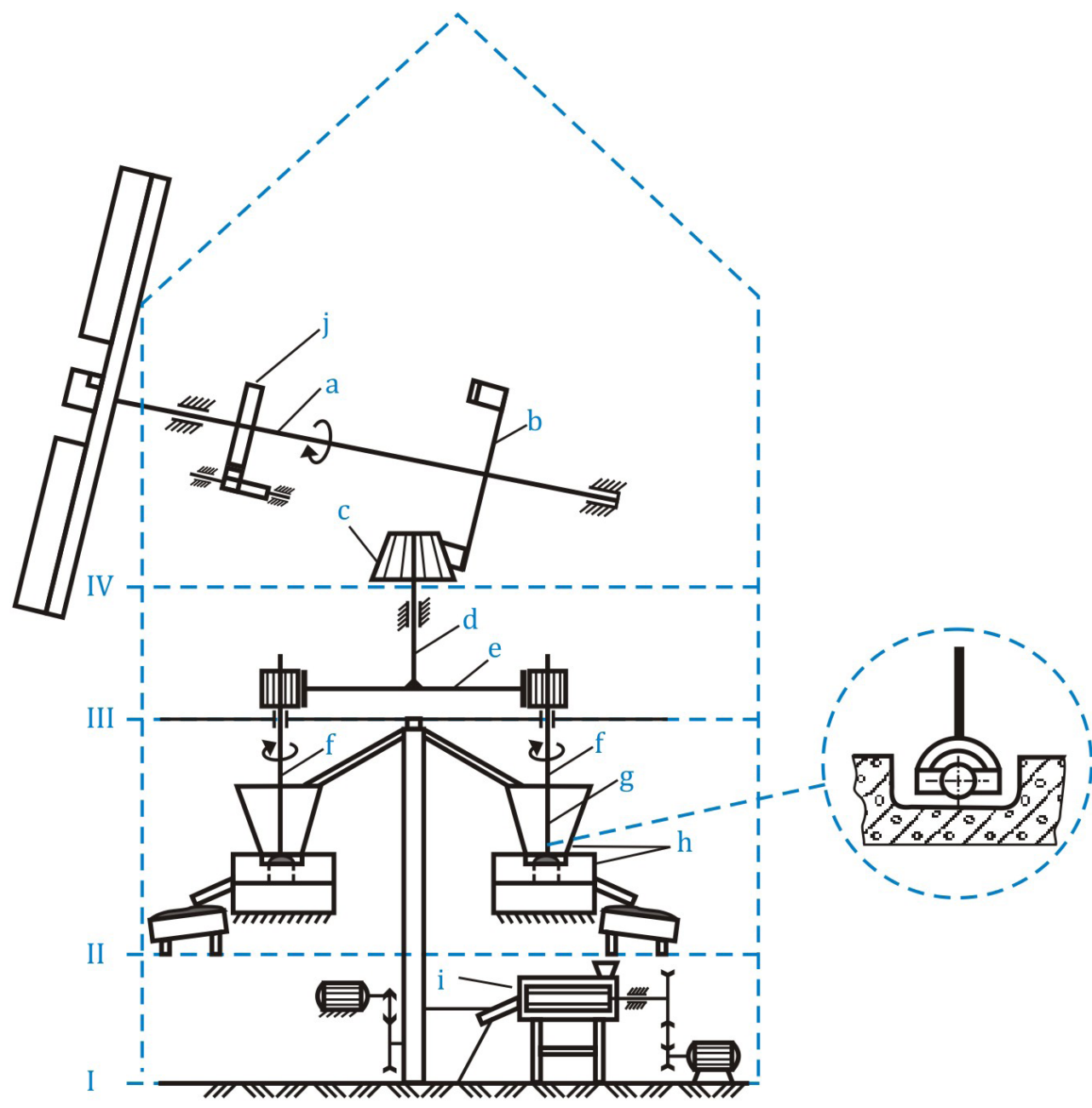

12. ábra. A szélmalom szerkezeti felépítése

I. lisztespad, II. kőpad, III. sebeskerékpad, IV. nagykerékpad

a. nagybálvány, b. nagykerék, c. nagyorsó, d. kisbálvány, e. sebeskerék,

f. kisorsó, g. duda, h. kö a garattal, i. koptató, j. fékrendszer.

a két kisdobkerék veszi át, amelyek a villás tengelyekre vannak rögzítve. Ennél az áttételnél jön létre a malom második gyorsító fokozata, amely 110-130 percenkénti fordulatával forgatja az őrlőkőpár felső, forgó kövét. Ezen a fordulaton történik a gabonaszemek aprítása, az őrlés. A malom emeletenkénti elemeit a 13-15. ábrák szemléltetik.

Az őrlőegységek a második szinten (első emeleten) helyezkednek el. Megfelelő szélsebesség esetén mindkét őrlőegység dolgozhat. Ha a szél- sebesség kisebb 2,0 m/s-nál, csak ez egyik őrlőegység üzemeltethető.

Az első szinten (földszint) található a gabona tisztítását végző, euréka szövettel bélelt koptató, porelszívó ventilátorával és porszűrő egységével. A gabonaszemek felületén található, étkezési célokra nem alkalmas szennyező anyagokat a koptató eltávolítja. A megkoptatott gabonát a gumilapátos felvonó továbbítja az őrlőegységek garatjába.

A malom energiaforrása a természetes szél. A szél mozgási energiáját a nagybálványnak ne- 


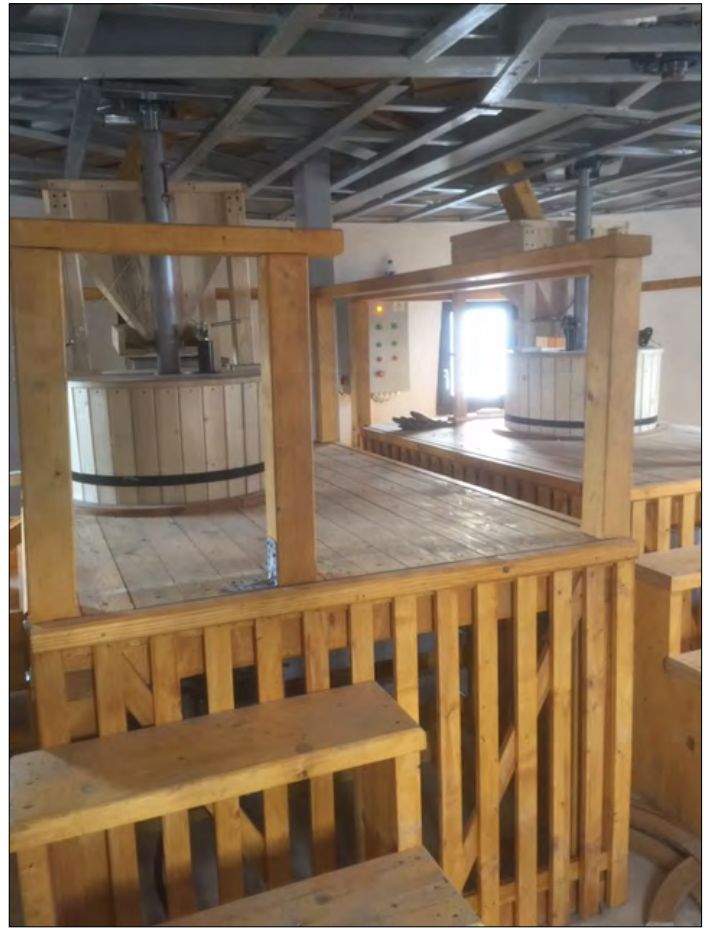

13. ábra. Az első emelet gépezete

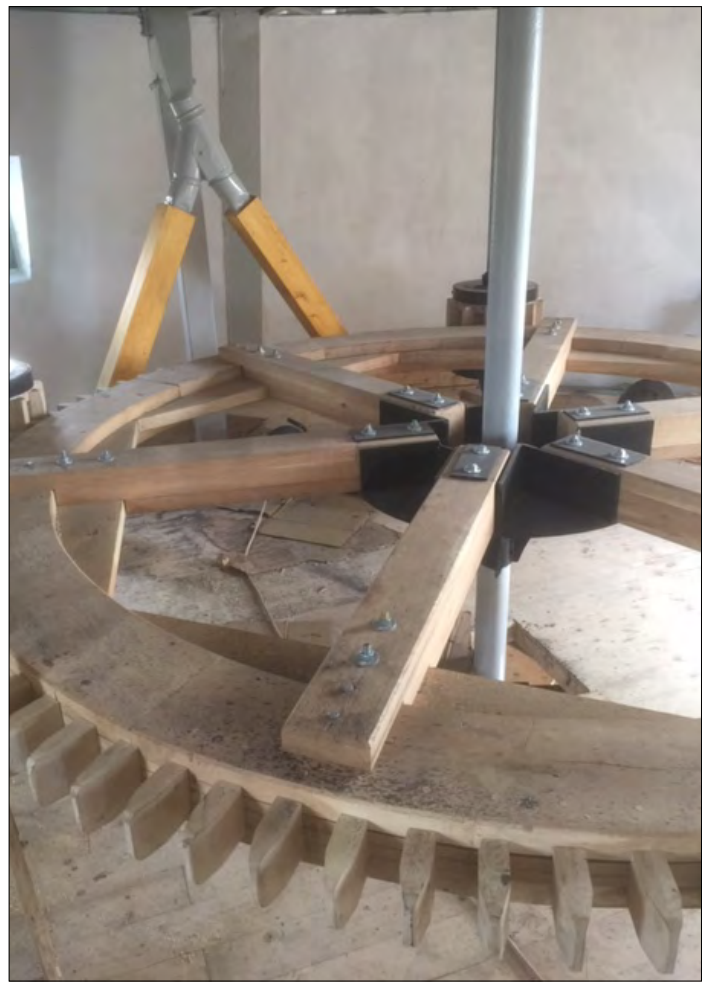

14. ábra. A harmadik emelet gépezete

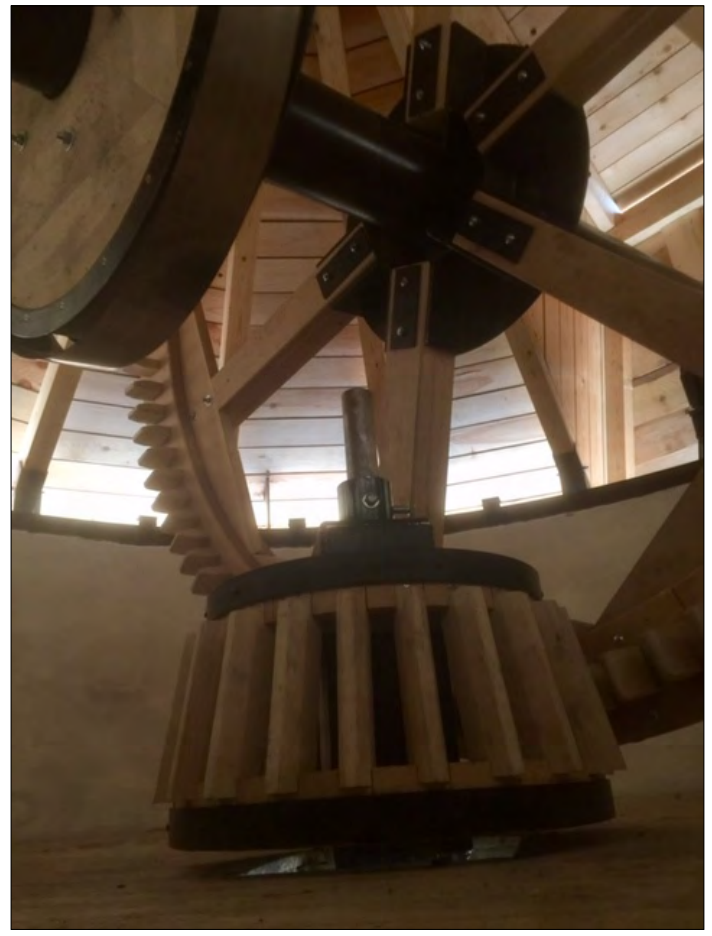

15. ábra. A negyedik emelet gépezete

vezett tengelyen található szélkerék vitorlái alakítják át forgómozgássá [7]. A vitorlákat mindig széllel szemben kell állítani. Ezt a műveletet egy erre a célra kialakított csörlővel kell elvégezni. A csörlő a tető alatti negyedik szinten található. A szélkerék a 16. ábrán látható.

A szélmalom őrlőegységei külön-külön is működtethetők. Ilyen esetben a nem használatos őrlőegységet ki kell kapcsolni, ami abból áll, hogy a villás tengelyt ki kell emelni a korongvasból, és kiemelt helyzetében le kell biztosítani az erre a célra kiképzett furatba beillesztett csap segítségével. Ezáltal a villás tengely forgómozgása nem szünik meg, de nem továbbítja ezt az őrlőkőnek.

\section{Következtetések}

A felsőszentiváni szélmalom újjáépítésével az Erdélyi Múzeum-Egyesület Műszaki Tudományok Szakosztálya ismét követendő példát statuált, bebizonyítva, hogy a szakosztály tagjainak többéves kutatómunkájának elméleti tudáshalmazát jó eredménnyel lehet gyakorlatban hasznosítani. A malomgépezet megtervezésében az említett, EME által szervezett technikatörténeti kutatómunka eredményei is fellelhetők. A többéves kutatómunka elméleti tudáshalmazát jó eredménnyel 


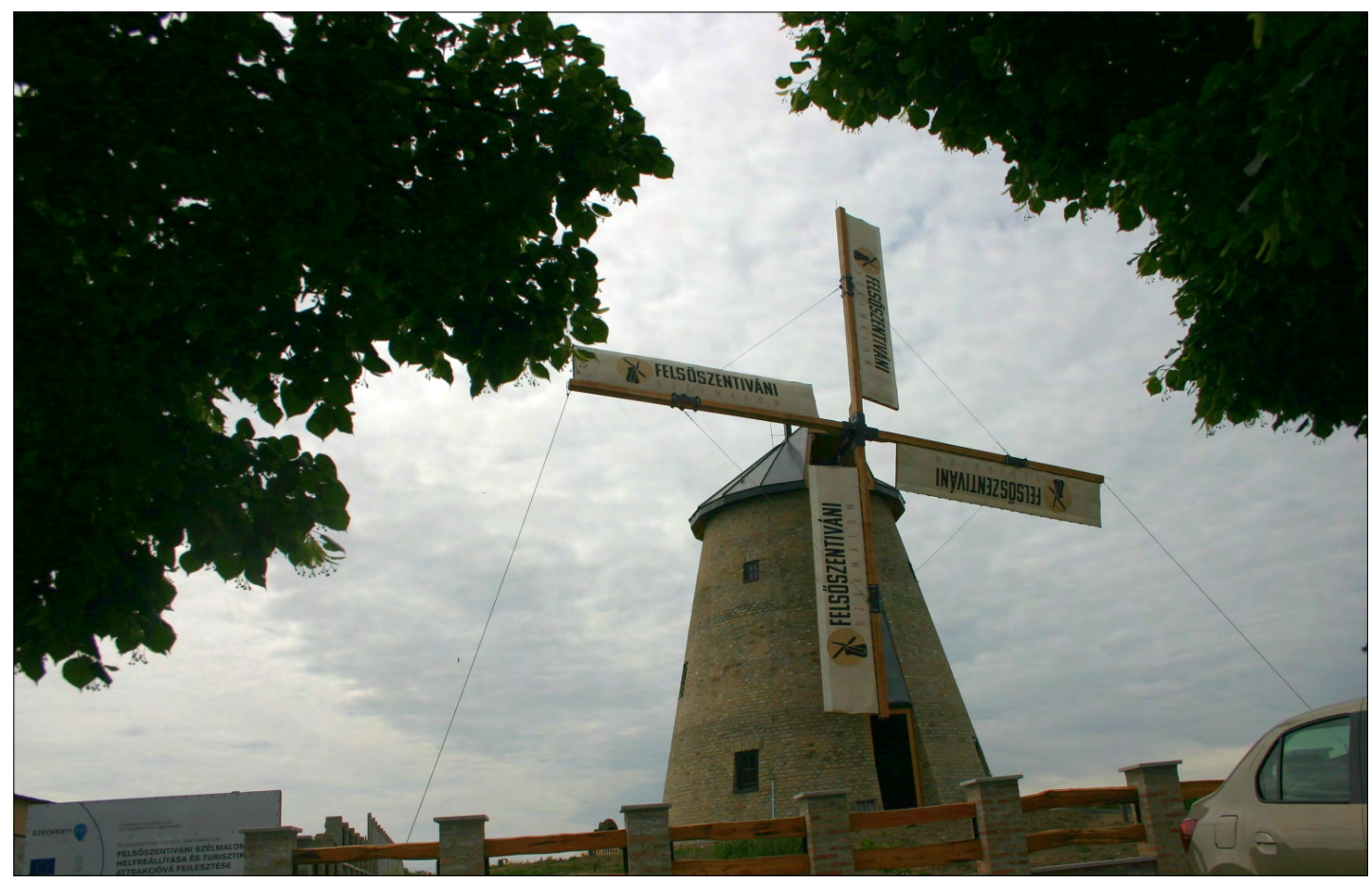

16. ábra. A szélmalom üzemkész látványa

lehet a gyakorlatban hasznosítani. Szentendre, Mohács [8], Baja, Felsőszentiván felújított vagy újjáépített malmai egyrészt ma már jelentős turisztikai célpontok, technikatörténeti szempontból is jelentős alkotások, másrészt tanúságtételei a megújuló energiaforrások alkalmazásának, különösen századunkban, amikor a fenntartható fejlődés egyik buktatója éppen az energia kérdése. Mindez követendő példa lehet a jövőben is.

\section{Szakirodalmi hivatkozások}

[1] Jean Gimpel: Revoluția industrială în Evul Mediu. Editura Meridiane, București, 1983. 29-32.

[2] Pongrácz Pál: A mezőgazdasági jellegü ipari építészet müemlékei. Építőipari és közlekedési Műszaki Egyetem Tudományos Közleményei, III/3. (1957).
[3] Márton László: Vízimalmok Erdélyben. PallasAkadémia Könyvkiadó, Csíkszereda, 2003. 33-34.

[4] Bitay Enikő, Márton László: Székelyföldi vízimalmok térben és időben. In: Márton László (szerk.): Fejezetek Székelyföld technikatörténetéből. Erdélyi Múzeum-Egyesület, 2019. https://doi.org/10.36337/2019-01-08.

[5] Kovács József: Szélmalmaink. Romanika Kiadó, Budapest, 2005. 47, 50.

[6] Lambrecht Kálmán: A magyar szélmalom. Budapest, 1911. 19.

[7] Johannes Mager: Mülenflügel und Wasserrad. VEB Fachbuchverlag, Leipzig, 1987. 14-15.

[8] Bitay Enikő, Márton László, Mohácsi Bugárszki Norbert, Angi Norbert: Egy ókori gabonaőrlő szerkezet - a taposómalom újjászületése. In: Müszaki Tudományos Közlemények, 2. (2015) 55-60. https://doi.org/10.33895/mtk-2015.02.04. 